\title{
Experimental Research and Metaanalysis
}

Pensar en Movimiento:

Revista de Ciencias del Ejercicio y la Salud

ISSN 1659-4436

Vol. 14, No.2, pp. 1- 16

Closing on December 31, 2016

\section{THIRST RESPONSE TO POST-EXERCISE FLUID REPLACEMENT NEEDS AND CONTROLLED DRINKING ${ }^{1}$}

\section{A RESPOSTA DA SEDE ÀS NECESSIDADES DE REPOSIÇÃO DE LÍQUIDO E À INGESTÃO CONTROLADA DEPOIS DO EXERCÍCIO}

\author{
Catalina Capitán-Jiménez, M.SC. ${ }^{(B, C, D, E)}$ and Luis Fernando \\ Aragón-Vargas, Ph.D.; FACSM ${ }^{(A, B, D, E)}$ \\ ktaucr@gmail.com \\ Human Movement Science Research Center, University of Costa Rica, Costa Rica
}

Original submission: 08/04/2016; resubmitted: 12/08/2016;

accepted: 12/16/2016; published: 12/24/2016.

Doi: http://dx.doi.org/10.15517/pensarmov.v14i2.25853

\begin{abstract}
Capitán-Jiménez, C. \& Aragón-Vargas, L.F. (2016). Thirst Response to Post-Exercise Fluid Replacement Needs and Controlled Drinking. Pensar en Movimiento: Revista de Ciencias del Ejercicio y la Salud, 14(2), 1-16. Perceived thirst (TP) was evaluated as a dependent variable: can it distinguish among several levels of acute dehydration, is it reliable, and how does it respond to the ingestion of a fixed water volume post exercise? In a repeated-measures design, eight physically active students (24.5 \pm 3.6 years, mean $\pm S D$ ), reported to the laboratory on four non-consecutive days. They remained at rest or exercised at $32 \pm 3^{\circ} \mathrm{C} \mathrm{db}$ and $65 \pm 6 \%$ rh to a randomly assigned dehydration equivalent to 1 , 2 , and $3 \%$ of body mass (BM). Following exercise, participants ingested a fixed water volume of $1.20 \%$ BM in 30 minutes; urine output, TP and plasma volume changes were
\end{abstract}

${ }^{1}$ Original submission in English. Available also in the Spanish-translated version in this journal. 
assessed every 30 minutes over 3 hours. Post-exercise TP was not different before and after showering $(p=0.860)$, but it was significantly different among conditions (TP $=2.50 \pm$ $0.45,4.44 \pm 0.72,6.38 \pm 0.82$, and $8.63 \pm 0.18$ for $0,1,2$, and $3 \% B M, p=0.001)$. TP was associated with net fluid balance $\left(r_{\text {part }}=-0.62, p<0.0001\right)$ but, soon after drinking, TP was the same regardless of dehydration $(p>0.05)$. Thirst perception is valid and reliable in the absence of drinking but it responds inappropriately to water intake.

Keywords: Dehydration; fluid intake; thirst perception; water-electrolyte balance; humans

\section{RESUMO}

Capitán-Jiménez, C. \& Aragón-Vargas, L.F. (2016). A resposta da sede às necessidades de reposição de líquido e à ingestão controlada depois do exercício. Pensar en Movimiento: Revista de Ciencias del Ejercicio y la Salud, 14(2), 1-16. Avaliou-se a percepção da sede (PS) como variável dependente: Pode esta distinguir entre distintos níveis de desidratação aguda? É confiável? Como responde à ingestão de um volume fixo de água depois do exercício? Conforme um desenho de medidas repetidas, oito estudantes fisicamente ativos (24.5 \pm 3.6 anos, média $\pm D E)$ relataram ao laboratório em quatro dias não consecutivos. Mantiveram-se em repouso ou se exercitaram a $32 \pm 3^{\circ} \mathrm{C}$ bs e $65 \pm 6 \%$ h até alcançar uma desidratação equivalente a 1,2 ou $3 \%$ da massa corporal (MC); a ordem das provas foi designada aleatoriamente. Depois do exercício, os participantes ingeriram um volume fixo de água equivalente a $1.20 \% \mathrm{MC}$ em 30 minutos. Mediu-se a eliminação de urina, a PS e as mudanças no volume plasmático a cada 30 minutos ao longo de três horas. Não houve diferença entre a PS pós-treino antes do banho e a PS depois do banho $(p=0.860)$, mas a PS sim foi distinta entre condições $(\mathrm{PS}=2.50 \pm 0.45,4.44 \pm 0.72,6.38 \pm 0.82$, e $8.63 \pm 0.18$ para $0,1,2$ e $3 \% \mathrm{MC}, p=$ 0.001). Observou-se uma associação entre PS e o equilíbrio neto de líquido $\left(r_{\mathrm{par}}=-0.62, p\right.$ $<0.0001)$, porém, pouco depois de beber, a PS foi igual sem importar a desidratação $(p>$ 0.05). A percepção da sede é válida e confiável enquanto não se bebe, mas responde inadequadamente à ingestão de água.

Palavras-chaves: Desidratação; ingestão de líquido; percepção da sede; equilíbrio de água e eletrólitos; humanos.

When humans exercise in the heat, they may incur dehydration to an extent that impairs performance; on the other hand, it is possible for triathletes, marathon, and ultramarathon runners to drink too much, resulting in asymptomatic and even symptomatic hyponatremia (Sawka et al., 2007). Different fluid replacement guidelines have been developed over time, trying to find a well-documented balance between the extremes of drinking too much and drinking too little. These guidelines, however, have been strongly 
criticized, to the extreme of suggesting they are more influenced by commercial interests than science (Cohen, 2012).

Meanwhile, drinking according to thirst has been advocated as the perfect solution to supplying needed fluids to exercising humans, but the advice has been handed out with scant experimental support. At the same time, there is evidence that thirst may not be enough (Maughan, Shirreffs, Merson, \& Horswill, 2005; Passe, Horn, Stofan, Horswill, \& Murray, 2007; Shirreffs, Armstrong, \& Cheuvront, 2004; Solera-Herrera \& Aragón-Vargas 2006), if enough means achieving zero net fluid balance at the end of observation, not only on average but for each individual. When the issue at hand is performance, there are very few studies supporting the claim that drinking to thirst during exercise is the best strategy for athletes (e.g. Goulet, 2011). To date, drinking to thirst remains an appealing yet not well-supported strategy for adequate hydration during and after exercise.

The physiological mechanisms associated with the detection and correction of cellular and extracellular fluid losses have been widely studied in animals and humans, but mostly in sedentary conditions (Adolph \& Dill, 1938; Corbit, 1968; Denton et al, 1999; Egan et al., 2003; Fitzsimons, 1961; Johnson, 1990; Johnson \& Thunhorst, 1997; Obika, Idu, George, Ajayi, \& Mowoe, 2009; Sagawa et al., 1992). While some of these mechanisms defend homeostasis by limiting additional fluid or sodium losses, it is only through the integration of input from several sources that the brain produces the neural state associated with thirst which will, in turn, cause the behaviors to replace water and sodium loss. Thirst is a perception, "the subjective experience evoked by fluid deficits" (Engell et al., 1987, p. 229) or, as explained by Johnson (2007), a motivational mechanism for the acquisition and consumption of water, created in the brain as the synthesis of multiple sources of information, both physiological and psychological.

A crucial question is whether thirst per se, understood as the drive to drink, is accurate and strong enough to result in the replacement of sweat losses from exercise and to maintain euhydration. Most studies related to this question have relied on monitoring voluntary fluid intake during exercise, as a surrogate measure of thirst (Passe et al., 2007; Peacock, Thompson, \& Stokes, 2012; Peacock, Thompson, \& Stokes, 2013; Rivera-Brown et al., 1999; Rivera-Brown, Ramirez-Marrero, Wilk, \& Bar-Or, 2008; Scaglioni, 2008; Shirreffs et al., 2005; Wilk, Rivera-Brown, \& Bar-Or, 2007). Voluntary fluid intake is, however, influenced by external factors such as the so-called Hawthorne effect (a change in behavior induced by the awareness of being observed, McCarney et al., 2007), ambient conditions and, of course, beverage temperature and composition (Hubbard et al., 1984; Hubbard, Szlyk \& Armstrong, 1990; Rivera-Brown et al., 1999; Rivera-Brown, RamirezMarrero, Wilk \& Bar-Or, 2008; Szlyk, Sils, Francesconi, Hubbard, \& Armstrong, 1989).

Several researchers have combined subjective reports of thirst with measures of voluntary fluid intake during or after exercise (Brown, McCarty, \& Millard-Stafford, 2011; Maresh et al., 2004). This latter approach makes sense, but it has an important limitation, namely, the possible confounding between cause and effect: higher thirst may drive a larger fluid intake, but fluid intake may in turn shut off thirst, independent of hydration status. 
The complexity of this topic warrants addressing one question at a time. This is more feasible with a post-exercise rehydration protocol than looking at hydration during exercise. The purpose of the present study was to evaluate thirst solely as a dependent variable: first, to verify if perceived thirst (PT) can clearly distinguish among several levels of acute dehydration. Second, to evaluate the reliability for the thirst scale used (Engell et al., 1987). Finally, to assess how PT responds over time to the ingestion of a fixed volume of water post exercise. This information was expected to shed some light on the plausibility of thirst functioning as a good measure of rehydration needs after exercise and sweat loss.

\section{METHODS}

Participants. Eight apparently healthy, physically active students (4 males, 4 females) age $=24.50 \pm 3.60$ y.o., weight $=73.09 \pm 12.67 \mathrm{~kg}$, and height $=1.69 \pm 0.06 \mathrm{~m}$ (mean \pm S.D.) provided written informed consent prior to participation in this study, as approved by the University of Costa Rica Ethics and Science Committee, \#VI-6446-2009. The experiment was part of a larger study designed to understand the diuretic response to a constant load of water. Each participant visited the laboratory on four different nonconsecutive days, one for each dehydration condition, in a repeated-measures design; the order of tests was randomized.

Procedures. Pre-dehydration and dehydration procedures for this type of study are commonly used (see Capitán-Jiménez \& Aragón-Vargas, 2012). Briefly, each participant reported to the laboratory at 7 a.m. after an overnight fast (at least 10 hours without solids or liquids). To estimate baseline hydration status upon arrival, he/she provided a urine sample which was analyzed for urine specific gravity (USG) with a manual refractometer (ATAGO®, model URC - Ne, d 1.000-1.050, Minato-ku, Tokyo, Japan), and discarded. After completely emptying their bladders, participants were weighed nude to the nearest 10 grams on a calibrated scale (e-Accuraß, model DSB291, Qingpu, Shanghai, China). This fasting body mass ( $\left(\mathrm{BM}_{\mathrm{fast}}\right)$ was used to calculate the water volume to be ingested by each individual. After sitting quietly for 15 minutes in a comfortable chair, a $5 \mathrm{~mL}$ blood sample was obtained by venipuncture, and a subjective perception of thirst (TP) was obtained from the response to the question How thirsty are you? on a 9-point scale $(1=$ not thirsty at all; 9 = very, very thirsty), developed by Engell et al. (1987). They ingested a standardized breakfast (750 kilocalories: $24.6 \%$ fat, $20.7 \%$ protein, and $54.7 \%$ carbohydrate; $250 \mathrm{~mL}$ of fluid, $1500 \mathrm{mg}$ sodium), and proceeded to rest for 30 minutes.

A second nude body weight was obtained at the end of the rest period (pre-exercise body mass, $\mathrm{BM}_{\text {pre }}$ ), together with another thirst perception score. When the individual protocol did not require dehydration $(0 \% \mathrm{BM})$, the participant rested for an additional 45 minutes outside the chamber; if the protocol for the day called for dehydration, he/she started intermittent exercise (25 minutes exercise, 5 minutes rest) alternating between pedaling on a cycle ergometer (Monark ${ }^{\circledR} 818 \mathrm{c}$, Vansbro, Sweden) and jogging on a treadmill (SportsArt ${ }^{\circledR}$ model 3250, Tainan City, Taiwan), as long as necessary to achieve a 
dehydration equivalent to 1,2 , or $3 \% \mathrm{BM}_{\text {pre; }}$ two types of exercise were chosen to reduce the possibility that participants would quit prematurely because of the pain or fatigue associated with only one exercise mode. Body mass was measured at the end of every 25 minutes of exercise with participants nude and dry. This dehydration protocol was performed in a controlled environment chamber $\left(32 \pm 3^{\circ} \mathrm{C}\right.$ dry bulb and $65 \pm 6 \%$ relative humidity); exercise intensity was $70 \%$ to $85 \%$ of maximum heart rate (estimated from 220 - age) and controlled with a heart rate monitor (Polar ${ }^{\circledR}$ Electro Oy model A1, Kempele, Finland).

A thirst score was obtained upon completion of the exercise or prolonged resting period, and each participant was instructed to take a cold shower and to completely empty his/her bladder in a $750 \mathrm{~mL}$ plastic container. This urine was weighed on a food scale (OHAUS ${ }^{\circledR}$ Compact Scales, model CS2000, Parsippany, NJ, USA) to the nearest $1 \mathrm{~g}$; no fluid intake was allowed at this time. All participants were weighed again nude and dry at this point to obtain post-exercise body mass (BMpost). They sat down and a $20 \mathrm{G}$ intravenous catheter (Vacutainer ${ }^{\circledR}$, Franklin Lakes, NJ, USA) was placed in the antecubital vein for repeated blood sampling, using a heparin seal. After sitting quietly for 10 minutes, a new thirst score and $5 \mathrm{~mL}$ blood sample were obtained, and each participant started his/her rehydration process.

Participants ingested a volume of water (temperature $=4.97 \pm 0.72^{\circ} \mathrm{C}$ ) equivalent to $1.20 \% \mathrm{BM}_{\mathrm{fast}}$, regardless of the condition, divided into three equal volumes, one every 10 minutes. Upon completing ingestion, they started a three-hour monitoring period at rest. Blood samples were obtained upon completing fluid intake and 60, 120 and 180 minutes later after sitting for at least 10 minutes. They emptied their bladders into labeled plastic containers upon completion of water ingestion (time 0), and every 30 minutes over three hours. The containers were weighed to the nearest $1 \mathrm{~g}$, and the volume was recorded assuming $1 \mathrm{~g}$ is equivalent to $1 \mathrm{~mL}$. Thirst perception was recorded at time 0 and every 30 minutes over three hours; all thirst perception ratings were obtained at ambient temperature $\left(26.0 \pm 0.9^{\circ} \mathrm{C}, 72.0 \pm 5.5 \%\right.$ r.h. $)$, outside the environmental chamber.

Blood hemoglobin was analyzed with a Sysmex ${ }^{\circledR}$ (Sant Just Desvern, Spain) XE2100 and XS-1000 using protocol IN-064; hematocrit with protocol IN-063, and total red blood cell count with protocol IN-066, all of them at an internationally certified laboratory. Resulting values were used to calculate plasma volume (PV) change according to Dill and Costill (1974).

Net fluid balance (NFB) was calculated for each 30-minute interval of the monitoring period relative to $\mathrm{BM}_{\text {pre, }}$ using body mass measurements, fluid intake and urine output.

Statistical analysis. We calculated descriptive statistics (mean and standard deviation) for age, body mass, and height in order to characterize the participants. We checked all variables for normality.

To verify that all participants showed the same characteristics under each condition, but achieved the desired differences, we performed several repeated-measures one-way 
analyses of variance for baseline USG, pre-exercise body mass, pre-exercise thirst, exercise time, actual dehydration incurred, and prescribed water intake.

To assess the reliability of the thirst scale we performed a repeated-measures twoway analysis of variance ( 4 conditions by 2 measurements) using only the post-exercise thirst scores obtained 30 minutes apart, before and after a cold shower. We calculated the intra-class correlation coefficient $(I C C)$ for test-retest reliability between these two thirst scores.

We performed a two-way analysis of variance with repeated measures on both condition and time for each dependent variable: thirst perception, plasma volume change, and net fluid balance. Post-hoc analyses were performed using a Bonferroni adjustment for multiple comparisons. We calculated the partial correlation coefficients and their statistical significance to assess the association among the same three dependent variables: TP, PV, and NFB. After confirmation, we tested a multiple regression model using thirst perception as the dependent variable, and plasma volume, net fluid balance, condition, measurement time, and subject as the potential predictors.

A statistical power analysis was performed a priori for the thirst variable. Calculated for a difference of 2 arbitrary units, 8 participants predicted a power of 0.860 .

\section{RESULTS}

Table 1 shows the reference values for each condition. There were no significant differences for baseline body mass, baseline urine specific gravity, pre-exercise thirst perception, or prescribed water intake $(p>0.05)$. Exercise time and actual dehydration were, however, significantly different $(p<0.0005)$, in line with the study design. An a posteriori power analysis using the urine volumes showed a power of 0.880 for eight subjects and a volume difference of $200 \mathrm{~mL}$.

Figure 1 shows post-exercise thirst perception. There was no significant interaction between condition and measurement time $(p=0.620)$. In addition, thirst perception was not different before taking a shower from 30 minutes later after showering $(p=0.860)$. The condition main effect was significant (thirst perception $=2.50 \pm 0.45,4.44 \pm 0.72,6.38 \pm$ 0.82 , and $8.63 \pm 0.18$ for $0,1,2$, and $3 \%$ dehydration, $p=0.001)$. Finally, the intra-class correlation coefficient $(I C C)$ between both post-exercise thirst scores (a test-retest correlation) was $r=0.973, p<0.0001$.

When the complete time of monitoring was analyzed, thirst perception showed a significant interaction between time and condition $(p<0.0001$, Figure 2$)$. The time main effect was significant $(p<0.0001)$, as well as the condition main effect $(p=0.0001)$. At the end of exercise, both the $3 \%(8.63[8.19,9.06]$, mean $[95 \% \mathrm{Cl}])$ and the $2 \%(6.38[4.43$, 8.35]) conditions were different from $0 \%(2.62[1.45,3.80])$, but $1 \%$ was not $(4.25$ [2.37, 6.13]). Post-hoc analysis for each condition over time showed a significant increase in thirst after exercise relative to pre-exercise $(p<0.05)$, and a return to pre-exercise thirst scores immediately after rehydration, for all except the $0 \%$ dehydration condition. 
Table 1

Reference values for each condition, prior to rehydration. Mean \pm S.D.

\begin{tabular}{lccccc}
\hline \multicolumn{1}{c}{ Variable } & 0\% BM & $\mathbf{1 \%} \mathbf{B M}$ & $\mathbf{2 \%} \mathbf{B M}$ & $\mathbf{3 \%} \mathbf{B M}$ & p-value \\
\hline Baseline USG & $1.015 \pm$ & $1.019 \pm$ & $1.018 \pm$ & $1.016 \pm$ & 0.392 \\
& 0.005 & 0.005 & 0.007 & 0.007 & \\
BMpre $(\mathrm{kg})$ & $73.66 \pm$ & $74.03 \pm$ & $73.59 \pm$ & $74.31 \pm$ & 0.132 \\
& 12.66 & 12.97 & 12.84 & 12.58 & \\
Pre-exercise thirst & $2.12 \pm 1.55$ & $1.62 \pm 0.51$ & $2.12 \pm$ & $2.37 \pm$ & 0.199 \\
$\begin{array}{l}\text { (a.u.) } \\
\text { Exercise time (min) }\end{array}$ & 0 & $32.5 \pm 10.0$ & $73.6 \pm$ & $87.5 \pm$ & $<0.001$ \\
& & & 12.8 & 13.3 & \\
$\begin{array}{l}\text { Actual dehydration } \\
\text { (\%BM) }\end{array}$ & $0.26 \pm 0.10$ & $1.07 \pm 0.10$ & $1.85 \pm$ & $2.93 \pm$ & $<0.001$ \\
$\begin{array}{l}\text { Prescribed water } \\
\text { intake (mL) }\end{array}$ & $877 \pm 152$ & $880 \pm 154$ & $877 \pm 154$ & $886 \pm$ & 0.136 \\
$\begin{array}{l}\text { Water temperature } \\
\left({ }^{\circ} \mathrm{C}\right)\end{array}$ & $5.0 \pm 0.9$ & $5.0 \pm 0.7$ & $4.9 \pm 0.8$ & $5.0 \pm 0.5$ & 0.945 \\
\hline
\end{tabular}

Source: The Authors

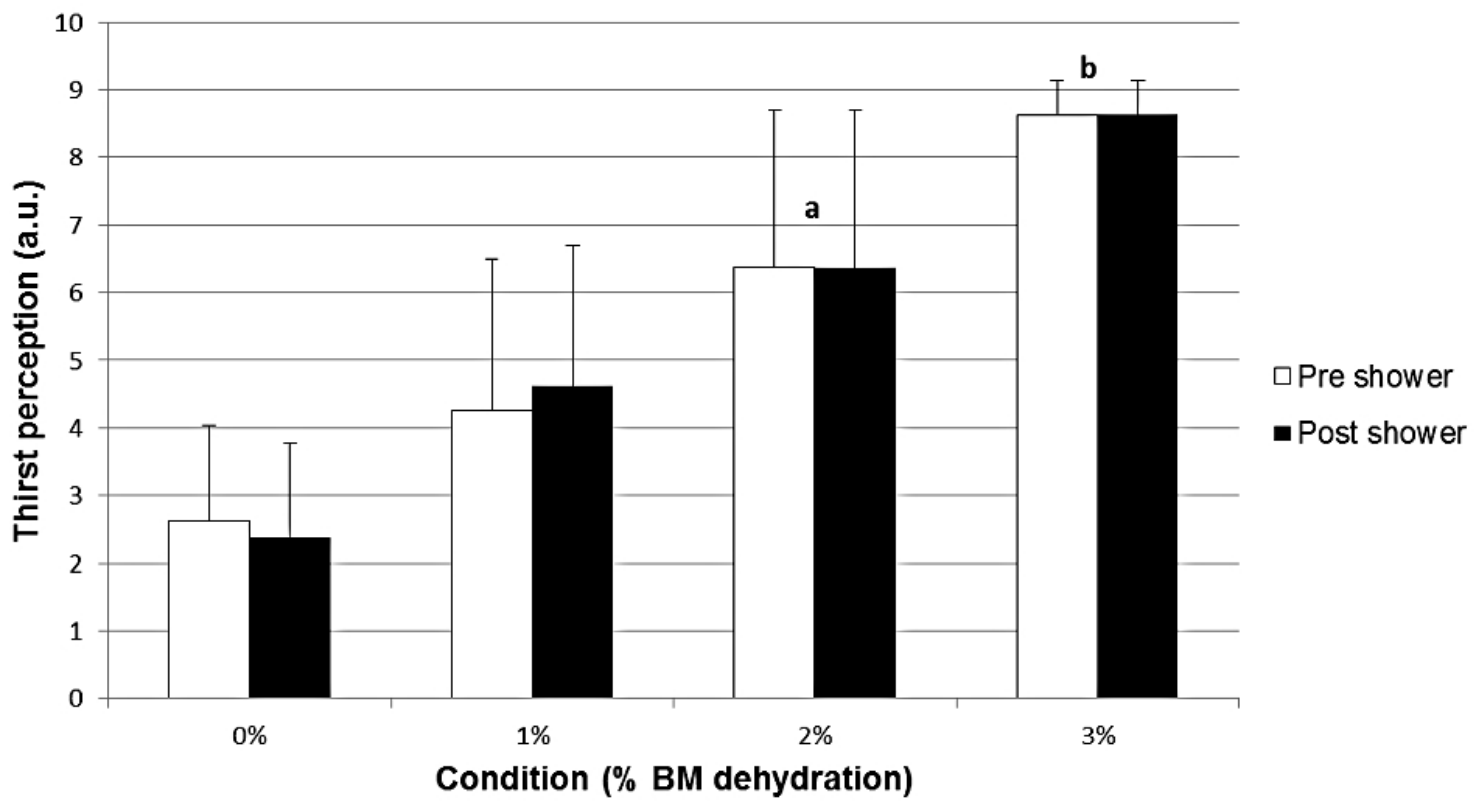

Figure 1. Post-exercise thirst perception. Bars represent means \pm SD. (a) different from $0 \%$ and $1 \%, p<0.05$. (b) different from $0 \%$ and $1 \%, p<0.005$. Source: The Authors 


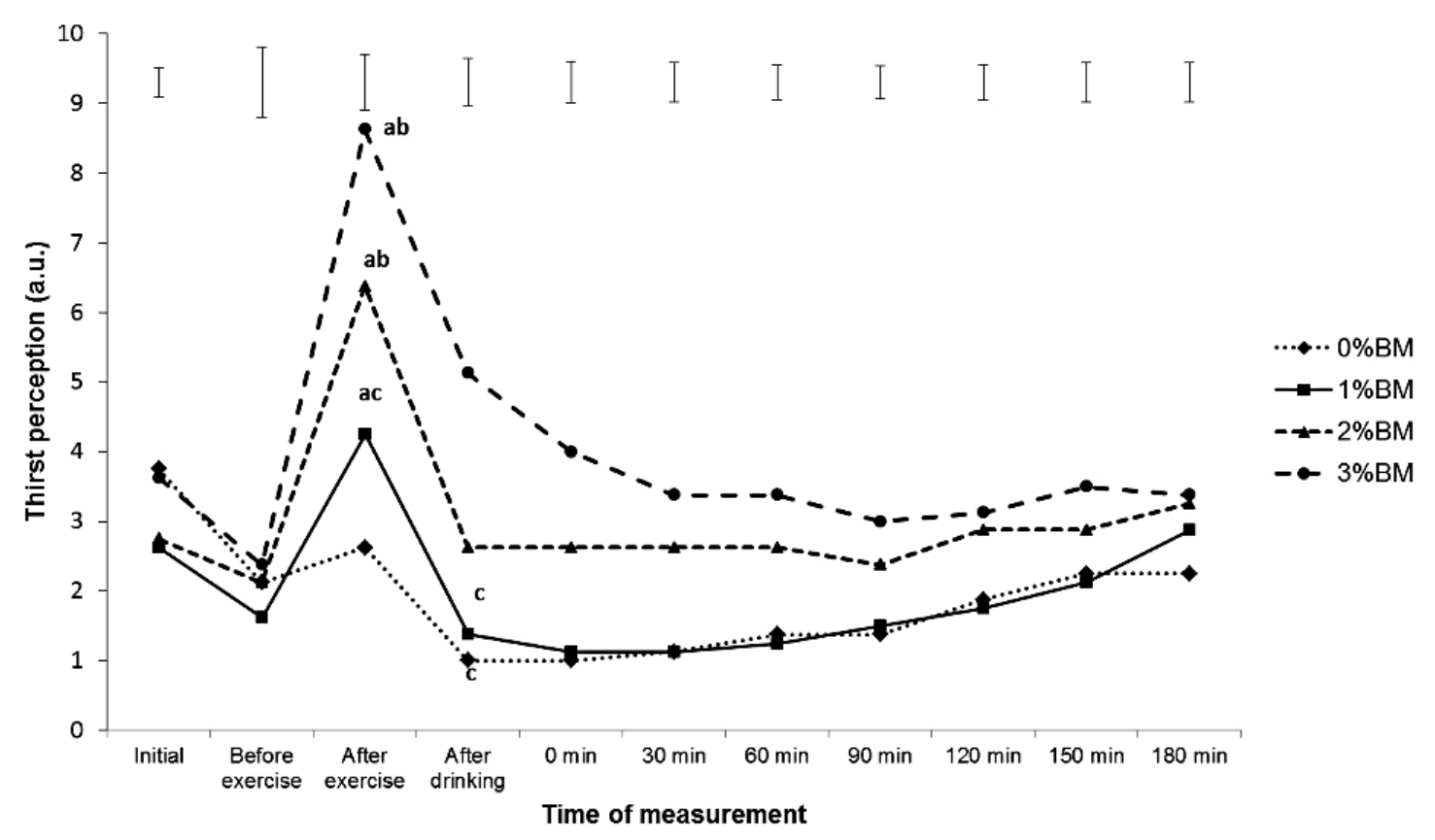

Figure 2. Thirst perception over time, by condition. Points are mean values; upper bars represent group standard errors of measurement. (a) Different from pre-exercise $(p<0.05)$. (b) Different from $0 \%$ and $1 \%(p<0.05)$ (c) Different from 3\% $(p<0.05)$. Source: The Authors.

Table 2 shows plasma volume changes for the different conditions. There was no significant interaction between condition and time of measurement $(p=0.883)$. There was no condition main effect $(p=0.064)$, but the main effect of measurement time was significant $(p<0.0001)$. Plasma volume was higher at all times after rehydration, compared to baseline $(p<0.05)$. It was also higher at 60,120 and 180 minutes compared to post-exercise.

Figure 3 shows net fluid balance. There was a significant interaction between time and condition $(p<0.0001)$, as well as significant main effects for both time $(p<0.0001)$ and condition $(p<0.0001)$. Net fluid balance was negative for all conditions after the exercise time, but it remained lower than zero after fluid intake only for the $1 \%, 2 \%$ and $3 \%$ dehydration conditions, with the exception of the first hour in the $1 \%$ dehydration condition. The $0 \%$ condition maintained a positive or neutral fluid balance until the end of monitoring. At this point, mean NFB was $-290 \mathrm{~g}$, with a $95 \%$ Confidence Interval from -627 to $47 \mathrm{~g}$. Net fluid balance was different among conditions at all time points except that the difference between $0 \%$ and $1 \%$ disappeared from the measures at 60 minutes and beyond.

Adjusted $\mathrm{R}^{2}$ for the multiple regression model (Figure 4) was $0.64(p<0.0001)$; NFB was a significant predictor $(F=28.125, p<0.0001)$, but PV was not $(F=0.284, p=0.595)$. The model also included subjects, condition, and time of measurement. Partial correlation coefficients were significant between TP and NFB $(-0.62, p<0.0001)$ and between PV and NFB $(0.31, p=0.001)$, but not between PV and TP $(-0.04, p=0.572)$. 
Table 2

Plasma volume change over time. Mean \pm S.D.

\begin{tabular}{|c|c|c|c|c|c|c|}
\hline Condition & $\begin{array}{l}\text { Base- } \\
\text { line }\end{array}$ & $\begin{array}{c}\text { After } \\
\text { exercise }^{a}\end{array}$ & $\begin{array}{c}\text { After re- } \\
\text { hydration }\end{array}$ & $\begin{array}{c}60 \text { min } \\
\text { after re- } \\
\text { hydration }\end{array}$ & $\begin{array}{c}120 \text { min } \\
\text { after re- } \\
\text { hydration }\end{array}$ & $\begin{array}{c}180 \text { min } \\
\text { after re- } \\
\text { hydration }^{\text {b }}\end{array}$ \\
\hline $0 \% \mathrm{BM}$ & 0 & $3.75 \pm 4.61$ & $\begin{array}{c}15.41 \pm 6.7 \\
5\end{array}$ & $\begin{array}{c}17.41 \pm 17.5 \\
5\end{array}$ & $\begin{array}{c}16.96 \pm 12.4 \\
0\end{array}$ & $11.51 \pm 6.58$ \\
\hline $1 \% \mathrm{BM}$ & 0 & $3.94 \pm 6.02$ & $\begin{array}{c}11.26 \pm 11 \\
36\end{array}$ & $13.18 \pm 6.77$ & $12.68 \pm 9.69$ & $\begin{array}{c}12.57 \pm 10.3 \\
8\end{array}$ \\
\hline $2 \%$ BM & 0 & $1.20 \pm 6.09$ & $9.60 \pm 9.90$ & $\begin{array}{c}12.20 \pm 14.2 \\
5\end{array}$ & $8.30 \pm 5.51$ & $4.59 \pm 5.32$ \\
\hline $3 \%$ BM & 0 & $\begin{array}{c}-2.29 \pm \\
6.26\end{array}$ & $\begin{array}{c}5.15 \pm 15.1 \\
7\end{array}$ & $7.64 \pm 11.96$ & $6.68 \pm 10.96$ & $5.65 \pm 9.45$ \\
\hline
\end{tabular}

Note: (a) Different from baseline, $p<0.05$. (b) Different from post-exercise, $p<0.05$. Source: The Authors

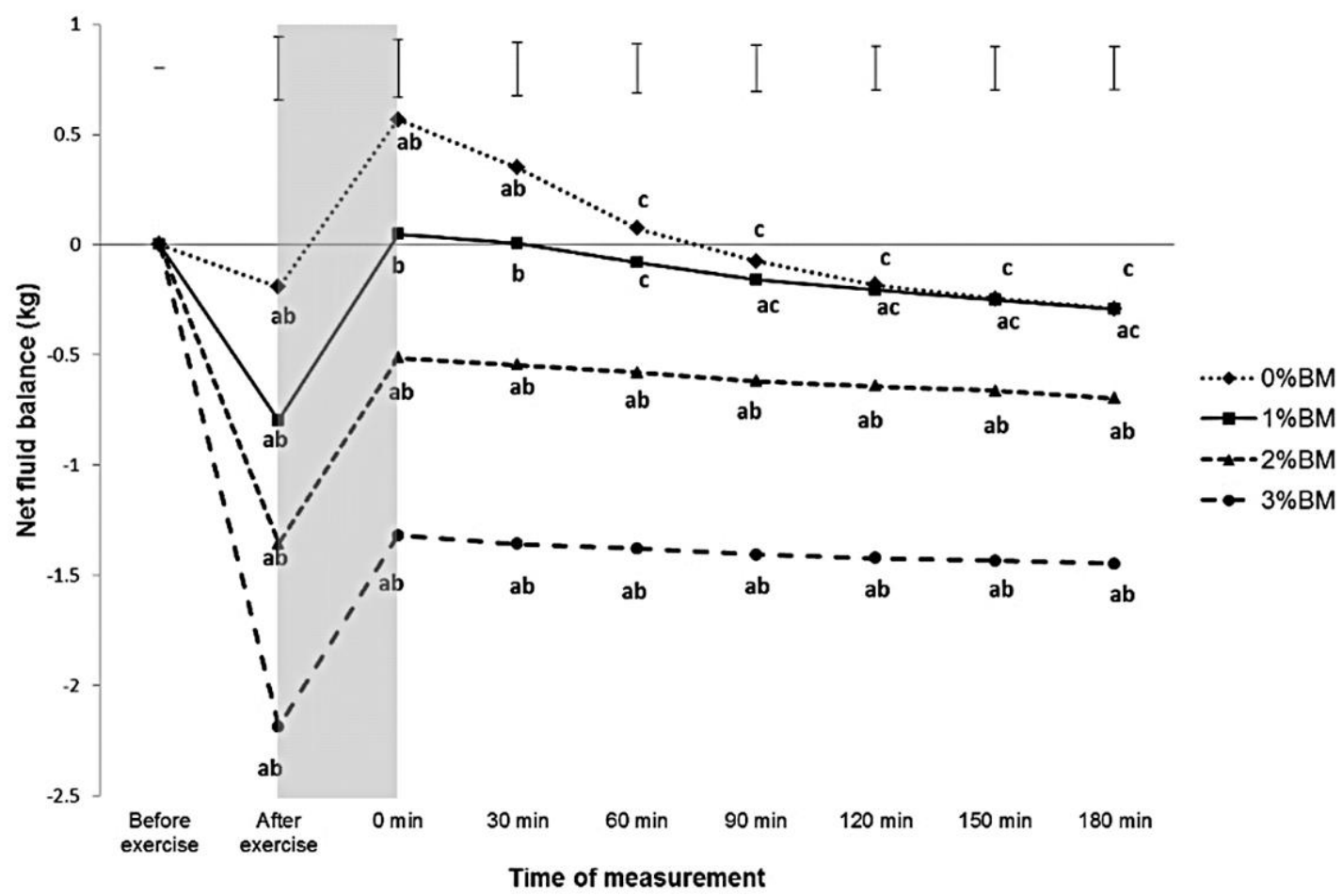

Figure 3. Net fluid balance over time, by condition. Points are mean values; upper bars represent group standard errors of measurement. Shaded area represents time of fluid ingestion. After exercise NFB $<0$ for all conditions, $p<0.05$. (a) different from the reference value $\left(B M_{\text {pre }}, \mathrm{p}<\right.$ 0.05). (b) different from all other conditions $(p<0.05)$. (c) different from $2 \%$ and $3 \%(p<0.05)$. Source: The Authors 


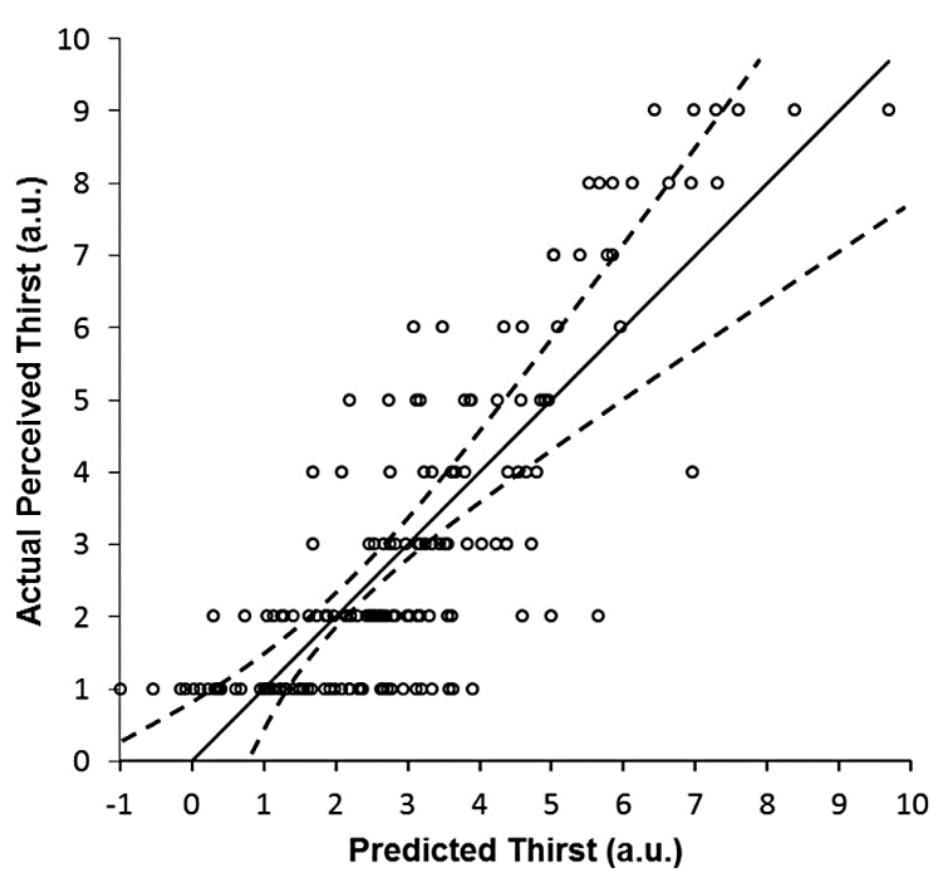

Figure 4. Multiple regression model $(n=160)$. Thirst perception at the end of exercise in the heat as the dependent variable. Predictors were NFB, PV, subject, condition, and measurement time. $\mathrm{R}^{2}{ }^{a d j}=0.64, p<0.0001$. Solid line is the line of adjustment; dotted lines represent $95 \% \mathrm{Cl}$. Source: The Authors

\section{DISCUSSION}

This study looked at the thirst response to ingesting a pre-determined, constant volume of water after exercising in the heat to different levels of dehydration. First, we confirmed that the subjective perception of thirst after exercise was able to detect levels of hypohydration equivalent to $2 \% \mathrm{BM}$ or greater: the scores for both $3 \%$ and $2 \%$ dehydration were different from $0 \%$, while $3 \%$ was also different from $1 \%$. Then we evaluated the reliability of Engell's thirst perception scale immediately after exercise by using a novel test-retest approach: rather than the conventional separation of 24 hours between tests-a protocol that in the present study would introduce extraneous, undesired variability -we separated the tests by only 30 minutes. Our protocol required each participant to take a cold shower, provide a urine sample, undress for a nude body weight measurement, and have a catheter placed in the forearm between the two post-exercise TP tests, for all the 0 , 1,2 , and $3 \%$ dehydration conditions in the study. This introduced enough "noise" to distract the participants without changing the physiological variables of interest. In the absence of water ingestion, TP results were reliable (ICC $r=0.973$ ). In addition, the difference between the two scores was not significant $(p=0.862)$. 
Engell et al. (1987) obtained two measures for each sensation, one when subjects first reached their target dehydration, and a second one the following morning, 12 to $15 \mathrm{~h}$ later. They stated that most sensations were significantly correlated using the test-retest method, but unfortunately no correlation was reported for "feel thirsty", our measure of interest; moreover, the period between tests may have added differences in the actual hypohydration at the time of the second measurements. We are not aware of other studies reporting the reliability of Engell's thirst scale.

Our main finding was that thirst perception decreased quickly with drinking regardless of dehydration, reaching pre-dehydration levels (TP $=2.53 \pm 0.85$ ) immediately after ingestion of about $880 \mathrm{~mL}$ and remaining there for the entire three hours of monitoring. In the $3 \% \mathrm{BM}$ dehydration condition, water intake represented only $40.4 \%$ of fluid loss and achieved a NFB of $\approx-1.3 \mathrm{~kg}$, which is far from euhydration. Therefore, while we found that thirst is strongly associated with an objective measure of hypohydration, i.e., net fluid balance, in the absence of water intake, the association weakens when subjects who are significantly dehydrated drink an insufficient amount. Using the same TP scale, Maresh et al. (2004) reported thirst being significantly reduced (from $\approx 5.5$ pre exercise to $\approx 3.2$ post exercise) in previously hypohydrated subjects who exercised in the heat for 90 min while drinking ad libitum; fluid intake was high, but they were still hypohydrated by about 3\%BM at the end of exercise. In another study comparing the rehydration properties of coconut water and other drinks (Pérez-Idárraga \& Aragón-Vargas, 2014), subjects ingested four aliquots equivalent to $30 \%$ of sweat loss each after exercising in the heat to $2.0 \%$ BM dehydration. Thirst perception was higher immediately after exercise but returned to baseline after drinking the first aliquot. Those two studies with different designs support our finding that thirst is quickly turned off after drinking water, even when the amount is insufficient to return to euhydration. Our study is in agreement with the statement by Cheuvront and Kenefick (2014), who pointed out that different receptors "trigger thirst satiety well before volume is fully restored" (p. 271); our findings, however, extend the results to show that this is not a transient effect, but one that lasts three hours.

In the present study, net fluid balance (a measure of hydration status) showed a very strong inverse association with thirst, while plasma volume change and thirst perception showed no association. Our multiple regression model confirmed NFB as a significant predictor of thirst, but not PV. This has already been noted by others: Engell et al. (1987) assessed thirst and measured voluntary fluid intake and many blood parameters during and after exercise in dry heat at 0, 3, 5, and 7\%BM hypohydration (0.9, 4.0, 5.9, and $7.3 \% \mathrm{BM}$ at the end of testing), concluding that hypovolemia contributes minimally to fluid intake (the contribution of perceived thirst was not reported). In their study, actual hypohydration showed a strong, direct association with thirst, and also with fluid intake.

Maresh et al. (2004) examined the responses of ten subjects walking in the heat for 90 minutes on four different occasions: previously euhydrated without fluid intake, previously hypohydrated $(\approx-3.8 \% \mathrm{BM}$ hypohydration) without fluid intake, previously euhydrated and drinking during exercise, or previously hypohydrated and drinking during exercise. Pre-exercise thirst was significantly higher for the hypohydrated conditions than 
for euhydration. Post-exercise thirst was even higher in the hypohydrated condition when subjects were not allowed to drink, but when fluid intake was allowed, post-exercise thirst was not different from that at pre-exercise euhydration. Thirst was found to respond predictably to dehydration, but plasma volume changes were not different between preexercise hydration conditions. Our results confirm a clear association between actual hypohydration and thirst perception before subjects were allowed to drink, and even an association between these two variables over the course of the entire experiment, while plasma volume was only weakly associated with thirst. This is not surprising, as Cheuvront and Kenefick (2014) point out that volume-mediated activation of thirst requires large plasma volume changes (about $10 \%$ of blood volume loss).

Thirst is considered by some as too elusive a variable, impossible to measure accurately (Greenleaf, 1992). Others take advantage of this characteristic and use the term imprecisely to suit their arguments, meaning anything from "dry mouth" to "what we actually drink". It is not surprising then that Greenleaf (1992) stated the beginning of his seminal paper Problem: thirst, drinking behavior, and involuntary dehydration that "the debate concerning the meaning of thirst is endless, so the emphasis here will be on actual fluid intake that can be measured." (p. 645). Thirst perception, however, can be measured reliably, although only in humans, as Johnson (2007) points out. The paper by Engell et al. (1987) is a good example; their scale has been widely used by others (Armstrong et al., 2014; Maresh et al., 2001; Maresh et al., 2004; Riebe et al., 1997), although there are good alternatives as the one described by Stachenfeld (2014). It may be argued that as any self-reported measure, TP could be sensitive to extraneous variables. Nevertheless, since the present experiment was part of a larger study designed to understand the diuretic response to a constant load of water, we consider that the participants had many different things to pay attention to which distracted them from the actual thirst reports-the main focus of this paper-and hence they were less likely to be distorted by subjectivity.

Thirst perception remains a difficult area of study. This study has an important limitation: despite using the most common thirst scale in the area, many participants reported the maximum values even when actual dehydration did not reach $3 \% \mathrm{BM}$. This "ceiling effect" complicates the analysis in an area of study where there are still many gaps. In addition, regardless of a calculated statistical power of 0.860 for the thirst measure, our sample size may be considered small by some. Nevertheless, the present results show statistically significant differences for self-reported thirst among objectively different dehydration levels, provided no fluid has been ingested. Further research is needed to clarify the reliability of thirst as a measure of hydration needs during and after exercise in the heat.

\section{CONCLUSIONS}

This study confirms that, in the absence of drinking, the subjective perception of thirst after exercise in the heat is able to detect dehydration equivalent to $2 \% \mathrm{BM}$ or greater. The measure is reliable and robust (not affected by taking a cold shower), and it shows a clear, significant association with net fluid balance $\left(r_{\text {part }}=-0.62, p<0.05\right)$. Thirst 
perception is, however, disproportionately reduced in dehydrated subjects after acute ingestion of water. When the goal is to replace all fluid lost through sweating after exercising in the heat, we deem thirst to be far from perfect as it responds inappropriately to fluid intake.

\section{ACKNOWLEDGMENTS}

This study was supported by University of Costa Rica project VI-245-B0-315. Thanks to Catalina Fernandez for assistance with literature review.

\section{REFERENCES}

Adolph, E.F. \& Dill, D.B. (1938). Observations on water metabolism in the desert. American Journal of Physiology, 123, 369-378. http://ajplegacy.physiology.org/ content/123/2/369

Armstrong, L. E., Johnson, E. C., Kunces, L. J., Ganio, M. S., Judelson, D. A., Kupchak, D. R., ...Williamson, K. H. (2014). Drinking to Thirst Versus Drinking Ad Libitum During Road Cycling. Journal of Athletic Training, 49(5), 624-631. doi: https://doi.org/10.4085/1062-6050-49.3.85

Brown, M. B., McCarty, N. A., \& Millard-Stafford, M. (2011). High-sweat Na+ in cystic fibrosis and healthy individuals does not diminish thirst during exercise in the heat. American Journal of Physiology: Regulatory, Integrative and Comparative Phisiology, 301(4), 1177-1185. doi: https://doi.org/10.1152/ajpregu.00551.2010

Capitán-Jiménez, C., \& Aragón-Vargas, L. F. (2012). Detection of Euhydration in Humans from the Diuresis Response to a Water Load. Medicina Sportiva, 16(1), 3035.Retrieved from http://www.kerwa.ucr.ac.cr/handle/10669/527?show=full

Cheuvront, S. \& Kenefick, R. (2014). Dehydration: physiology, assessment, and performance effects. Comprehensive Physiology 4(1), 257-285. doi: https://doi.org/10.1002/cphy.c130017

Cohen, D. (2012). The truth about sports drinks. BMJ, 345. doi: https://doi.org/10. 1136/bmi.e4737

Corbit, J. D. (1968). Cellular dehydration and hypovolaemia are additive in producing thirst. Nature, 218, 886-887. doi: https://doi.org/10.1038/218886a0

Denton, D., Shade, R., Zamarippa, F., Egan, G., Blair-West, J., McKinley, M., \& Fox, P. (1999). Correlation of regional cerebral blood flow and change of plasma sodium concentration during genesis and satiation of thirst. Proceedings of the National Academy of Sciences of the United States of America 96(5), 2532-2537. https://doi.org/10.1073/pnas.96.5.2532

Dill, D. B., \& Costill, D. L. (1974). Calculation of percentage changes in volumes of blood, plasma, and red cells in dehydration. Journal of Applied Physiology, 37(2), 247248. Retrieved from http://jap.physiology.org/content/jap/37/2/247.full.pdf 
Egan, G., Silk, T., Zamarippa, F., Williams, J., Federico, P., Cunnington, R., ..., \& Denton, D. (2003). Neural correlates of the emergence of consciousness of thirst. Proceedings of the National Academy of Sciences of the United States of America 100(25), 15241-15246. doi: https://doi.org/10.1073/pnas.2136650100

Engell, D. B., Maller, O., Sawka, M. N., Francesconi, R. N., Drolet, L., \& Young, A. J. (1987). Thirst and fluid intake following graded hypohydration levels in humans. Physiology \& Behavior, 40(2), 229-236. doi: https://doi.org/10.1016/00319384(87)90212-5

Fitzsimons J. T. (1961). Drinking by rats depleted of body fluid without increase in osmotic pressure. Journal of Physiology, 159(2), 297-309. doi: https://doi.org/10.1113/ iphysiol.1961.sp006809

Goulet, E. D. (2011). Effect of exercise-induced dehydration on time-trial exercise performance: a meta-analysis. British Journal of Sports Medicine, 45(14), 11491156. doi: https://doi.org/10.1136/bjsm.2010.077966

Greenleaf, J. E. (1992). Problem: Thirst, drinking behavior and involuntary dehydration. Medicine and Science in Sports Exercise, 24(6), 645-656. doi: https://doi.org/10. 1249/00005768-199206000-00007

Hubbard, R. W., Sandick, B. L., Matthew, W. T., Francesconi, R. P., Sampson, J. B., Durkot, M. J., ... Engell, D. B. (1984). Voluntary dehydration and alliesthesia for water. Journal of Applied Physiology, 57(3), 868-875. Retrieved from http://jap.physiology.org/content/57/3/868

Hubbard, R. W., Szlyk, P. C., \& Armstrong, L. E. (1990). Influence of thirst and fluid palatability on fluid ingestion during exercise. Gisolfi, C. V., \& Lamb, D. R. (Eds.), Perspectives in exercise science and sports medicine: Vol. 3 Fluid homeostasis during exercise (pp. 39-95). Carmel, IN: Cooper Publishing Group.

Johnson, A. K. (1990). Brain mechanisms in the control of body fluid homeostasis. Gisolfi, C. V., \& Lamb, D. R, (Eds.), Perspectives in exercise science and sports medicine: Vol. 3. Fluid homeostasis during exercise (pp. 347-424). Carmel, IN: Cooper Publishing Group.

Johnson, A. K. (2007). The sensory psychobiology of thirst and salt appetite. Medicine and Science in Sports and Exercise, 39(8), 1388-1400. doi: https://doi.org/10.1249/ mss.0b013e3180686de8

Johnson, A. K., \& Thunhorst, R. L. (1997). The neuroendocrinology of thirst and salt appetite: visceral sensory signals and mechanisms of central integration. Frontiers and Neuroendocrinology, 18(3), 292-353. doi: https://doi.org/10.1006/ frne.1997.0153

Maresh, C. M., Gabaree-Boulant, C. L., Armstrong, L. E., Judelson, D. A., Hoffman, J. R., Castellani, J. W., ... Casa, D. J. (2004). Effect of hydration status on thirst, drinking, and related hormonal responses during low-intensity exercise in the heat. Journal of Applied Physiology, 97(1), 39-44. doi: https://doi.org/10.1152/ japplphysiol.00956.2003 
Maresh, C. M., Herrera-Soto, J. A., Armstrong, L. E., Casa, D. J., Kavouras, S. A., Hacker, F. T. Jr., ... Scheett, T. P. (2001). Perceptual responses in the heat after brief intravenous versus oral rehydration. Medicine and Science in Sports and Exercise, 33(6), 1039-1045. Retrieved from https://doi.org/10.1097/00005768-200106000$\underline{00025}$

Maughan, R. J., Shirreffs, S. M., Merson, S. J., \& Horswill, C. A. (2005). Fluid and electrolyte balance in elite male football (soccer) players training in a cool environment. Journal of Sports Sciences, 23(1), 73-79. doi: https://doi.org/10.1080/02640410410001730115

McCarney, R., Warner, J., Iliffe, S., Van Haselen, R., Griffin, M., \& Fisher, P. (2007). The Hawthorne Effect: a randomised, controlled trial. BMC Medical Research Methodology, 7, 30. doi: https://doi.org/10.1186/1471-2288-7-30

Obika, L. F., Idu, F. K., George, G. O., Ajayi, O. I., \& Mowoe, R. S. (2009). Thirst perception and drinking in euhydrate and dehydrate human subjects. Nigerian Journal of Physiological Sciences, 24(1), 25-32. https://doi.org/10.4314/ njps.v24i1.46377

Passe, D., Horn, M., Stofan, J., Horswill, C., \& Murray, R. (2007). Voluntary dehydration in runners despite favorable conditions for fluid intake. International Journal of Sport Nutrition and Exercise Metabolism, 17(3), 284-295.doi: https://doi.org/10.1123/ ijsnem.17.3.284

Peacock, O. J., Thompson, D., \& Stokes, K. A. (2012). Voluntary drinking behaviour, fluid balance and psychological affect when ingesting water or a carbohydrateelectrolyte solution during exercise. Appetite, 58(1), 56-63. https://doi.org/10.1016/ j.appet.2011.08.023

Peacock, O. J., Thompson, D., \& Stokes, K. A. (2013). Impact of a carbohydrateelectrolyte drink on ingestive behaviour, affect and self-selected intensity during recreational exercise after 24-h fluid restriction. Appetite, 60(1), 5-12. doi: https://doi.org/10.1016/j.appet.2012.10.017

Pérez-Idárraga, A., \& Aragón-Vargas, L. F. (2014). Postexercise rehydration: potassiumrich drinks versus water and a sports drink. Applied Physiology, Nutrition, and Metabolism, 39(10), 1167-1174. doi: https://doi.org/10.1139/apnm-2013-0434

Riebe, D., Maresh, C. M., Armstrong, L. E., Kenefick, R. W., Castellani, J. W., Echegaray, M, E., Clark, B. A., \& Camaione, D. N. (1997). Effects of oral and intravenous rehydration on ratings of perceived exertion and thirst. Medicine and Sciences in Sports and Exercise, 29(1), 117-124. doi: https://doi.org/10.1097/00005768$199701000-00017$

Rivera-Brown A. M.., Gutierrez, R.., Gutierrez J.C., Padro, C., Frontera, W., \& Bar-Or, O. (1999). Drink composition, voluntary drinking, and fluid balance in exercising, trained, heat-acclimatized boys. Journal Applied Physiology, 86(1), 78-84. Retrieved from http://jap.physiology.org/content/86/1/78.long 
Rivera-Brown, A., M., Ramirez-Marrero, F. A., Wilk, B., \& Bar-Or, O. (2008). Voluntary drinking and hydration in trained, heat-acclimatized girls exercising in a hot and humid climate. European Journal of Applied Physiology, 103(1), 109-116. doi: https://doi.org/10.1007/s00421-008-0682-1

Sagawa, S., Miki, K., Tajima, F., Tanaka, H., Choi, J. K., Keil, L. C.,Greenleaf, J. E. (1992). Effect of dehydration on thirst and drinking during immersion in men. Journal of Applied Physiology, 72(1), 128-34. Retrieved from http://jap.physiology.org/content/72/1/128.long

Sawka, M. N., Burke, L. M., Eichner, E. R., Maughan, R. J., Montain, S. J., \& Stachenfeld, N. S. (2007). American College of Sports Medicine position stand. Exercise and Fluid Replacement. Medicine and Science in Sports and Exercise, 39(2), 377-390. doi: https://doi.org/10.1249/mss.0b013e31802ca597

Scaglioni, P. (2008). Ingesta voluntaria de líquido y cambio en el gusto con opción de dos bebidas durante entrenamiento en ciclismo. Pensar En Movimiento: Revista del ciencias del ejercicio $y$ la salud, 6(1), 24-33. doi: https://doi.org/10.15517/pensarmov.v6i1.369

Shirreffs S. M., Aragon-Vargas L. F., Chamorro M., Maughan R. J., Serratosa L., \& Zachwieja J. J. (2005). The Sweating Response of Elite Professional Soccer Players to Training in the Heat. International Journal of Sports Medicine, 26(2), 9095. doi: https://doi.org/10.1055/s-2004-821112

Shirreffs, S. M., Armstrong, L. E., \& Cheuvront, S. N. (2004). Fluid and electrolyte needs for preparation and recovery from training and competition. Journal of Sports Sciences, 22(1), 57-63. doi: https://doi.org/10.1080/0264041031000140572

Solera-Herrera, A., \& Aragón-Vargas, L. F. (2006). Deshidratación y sobrehidratación voluntarias durante el ejercicio en el calor: posibles factores relacionados. Pensar en Movimiento: Revista De Ciencias Del Ejercicio y La Salud, 4(1), 22-33. doi: https://doi.org/10.15517/pensarmov.v4i1.410

Stachenfeld, N. S. (2014). The Interrelationship of Research in the Laboratory and the Field to Assess Hydration Status and Determine Mechanisms Involved in Water Regulation During Physical Activity. Sports Medicine, 44(1), 97-104. doi: https://doi.org/10.1007/s40279-014-0155-0

Szlyk, P. C., Sils, I. V., Francesconi, R. P., Hubbard, R. W., \& Armstrong, L. E. (1989). Effects of water temperature and flavoring on voluntary dehydration in men. Physiology \& Behavior, 45(3), 639-647. doi: https://doi.org/10.1016/00319384(89)90085-1

Wilk, B., Rivera-Brown, A. M., \& Bar-Or, O. (2007). Voluntary drinking and hydration in non-acclimatized girls exercising in the heat. European Journal of Applied Physiology, 101(6), 727-734. doi: https://doi.org/10.1007/s00421-007-0539-z

Contribution: A- Funding, B- Study design, C- Data collection, D- Statistical analysis and interpretation of results, E- Manuscript preparation. 